\title{
Posthumanism, education and decolonization: A conversation with Michalinos Zembylas
}

\section{Jacky Barreiro \\ Simon Fraser University \\ Melisse Vroegindeweij \\ Utrecht University \\ Magali Forte \\ Simon Fraser University}

\section{Michalinos Zembylas}

Open University of Cyprus \& Nelson Mandela University

DOI: https://doi.org/10.1344/inmr.v1i2.31972

\section{Abstract}

The work of creating decolonized futures has been a particularly important undertaking in educational contexts, for which posthumanist and new materialist theories provide useful insights. Yet, how decolonization is to be achieved and whose responsibility it is remains up for discussion. This intra-view focuses on the tensions between decolonizing practices and posthumanism, and their implications for education: What can('t) these theories do to decolonize education? And how do we engage in posthuman practices in education without overstepping, appropriating, or (re)colonizing Indigenous epistemologies? Thinking through these questions, in this intra-view we engage in a conversation with Michalinos Zembylas.

\section{Keywords}

Decolonization; posthumanism; education; affect; ally; incommensurability. 
"If your goal is to prioritize decolonization, one might question whether you actually need posthumanism to serve this project. I'm not saying that they shouldn't be used together. ... We have to be conscious that using them together entails intellectual and political consequences and implications that need to be spelled out."

Michalinos Zembylas

\section{Introduction}

In the last decades, the concept of decolonization has become a pressing issue in postcolonial and settler colonial states. While it is increasingly acknowledged that decolonization is a crucial step for our societies to heal and move forward in socially just ways, what decolonization looks like, how it is to be achieved, and whose responsibility it is remains up for discussion. The work of creating decolonized futures has been a particularly important undertaking in educational contexts, as prevalent neoliberal educational systems continue to reproduce colonial and Eurocentric practices and worldviews. Posthumanist and new materialist theories provide useful insights to think about these issues, since they emphasize the discursive-material relationality and performativity of the world. Yet, questions arise: What can and can't these theories do to decolonize education? And how compatible are they with Indigenous ways of knowing/being? Following from these questions, we ask: What are the implications of being posthuman and engaging in decolonial practices? How do we engage in posthuman practices in education without overstepping, appropriating, or (re)colonizing Indigenous epistemologies?

Thinking through these questions, we engaged in a conversation with Michalinos Zembylas, who has written extensively about decolonization, posthumanism, and education. Zembylas is Professor of Educational Theory and Curriculum Studies at the Open University of Cyprus and Honorary Professor at Nelson Mandela University in the Chair for Critical Studies in Higher Education Transformation. His research interests focus on, amongst others, emotion and affect in relation to social justice pedagogies, intercultural and peace education, human rights education and 
citizenship education. He has also authored and co-authored several books. A couple of his recent books include Critical human rights education: Advancing social-justiceoriented educational praxes (with A. Keet), Psychologized language in education: Denaturalizing a regime of truth (with Z. Bekerman), and Socially just pedagogies in higher education (co-edited with V. Bozalek, R. Braidotti, and T. Shefer). In 2016, he received the Distinguished Researcher Award in Social Sciences and Humanities from the Cyprus Research Promotion Foundation.

Our conversation with Zembylas took place on April 2nd, 2020. We originally planned to have a roundtable discussion organized by the Reading/Thinking/Doing (RTD) club ${ }^{1}$ with Zembylas during his visit to Simon Fraser University (BC, Canada) planned on that same day. However, the format changed as his visit was cancelled due to the Covid19 pandemic. Because of this original plan, it was important for us to find a way to have members of the RTD club - and possibly any others who were interested - join our conversation. So, as the conversation was moved online, Jacky, Melisse and Magali decided to run two ZOOM meetings simultaneously. The first ZOOM meeting involved the three of us and Zembylas (who joined us from Cyprus), and the second one served as a platform for twelve additional participants. ${ }^{2}$ They were able to listen to the live interview and to use the chat feature to ask questions and/or contribute comments. While we prepared some questions for Zembylas ahead of time, we did not want our conversation to be a strictly structured interview. The questions and comments from the participants were therefore enriching and much appreciated. We also audio recorded ${ }^{3}$ the $Z 0 O M$ conversation, which can be accessed here.

In the weeks before our conversation took place, we selected three papers to (re)read and generate thinking and questions: Affect, race and white discomfort in schooling (2018a) and The entanglement of decolonial and posthuman perspectives (2018b) both written by Zembylas, and Decolonization is not a metaphor (2012) written by Eve

\footnotetext{
1 The Reading/Thinking/Doing (RTD) club is a scholarly event organized by Jacky Barreiro and Magali Forte, both doctoral candidates in the Faculty of Education at Simon Fraser University. The RTD club is an open event attended by graduate students and professors. It gathers in the Research Hub once a month to discuss different concepts and theories within posthumanism and new materiality.

2 Participants, whose comments and questions were included in the intra-view, provided consent for their contributions to be included in the written and audio version.

3 The written and audio versions of the intra-view have been edited for clarity and cohesiveness. Consequently, the written version of the intra-view is not an exact transcript of the audio version. However, the meaning and spirit of the conversation have been preserved in both versions.
} 
Tuck $^{4}$ and K. Wayne Yang. The following conversation emerged from our collective engagement with these readings, focusing on the tensions between decolonizing practices and posthumanism, as well as the entanglements of decolonization and pedagogical practices in education. We invite our readers to become part of this intraview $^{5}$ and think with us about these tensions and entanglements, and the "consequences and implications" that unfold when posthumanism and decolonization are brought together, as Zembylas suggests in the quote above.

\section{Intra-view}

Michalinos Zembylas (MZ): Hello?

Jacky Barreiro (JB), Melisse Vroegindeweij (MV) \& Magali Forte (MF) (together): Hello! $\mathrm{Hi}$ !

JB: It's great to have you here with us.

MZ: Can you see me?

JB, MV \& MF: Yes!

MZ: Oh good! I can see you too. And you can hear me?

MF: We can hear you.

JB: Fantastic!

MZ (laughing): Nice to see you all.

JB: Ok. Before we start with this intra-view, we, the organizers - Jacky, Melisse, and Magali, think it is important to acknowledge the current state of the world due to the coronavirus pandemic. As people everywhere struggle to keep safe and sane in the best possible ways available to each one, we too feel the strains and constraints imposed by the virus itself and by governments. We want to express first our solidarity with those whose circumstances might make their struggles even harder. In these strange times we all live in, this intra-view is for us a way to convey hope that, as a

\footnotetext{
${ }^{4}$ Eve Tuck is Unangax and an enrolled member of the Aleut Community of St. Paul Island, Alaska.

${ }^{5}$ By intra-view, we mean the assemblage of all elements and processes described in our introduction. As Barreiro \& Vroegindeweij (2020) explain, the concept of intra-view refers to "the mutual constitution of questions, responses, comments and technologies...from which new understandings and questions emerge" (p. 139).
} 
society, we will move on, but also that, as a society, we still need to think about and do what is required of each one to create a better place for all.

My name is Jacky Barreiro, and as the co-editor of the Intra-view section of the Matter: Journal of New Materialist Research and a co-founding member of the RTD club, I would like to welcome everyone who is connected today, both as listeners to the intraview and as participants in this ZOOM conversation with our special guest, Michalinos Zembylas. Thank you Professor Zembylas for accepting our invitation to this conversation.

$M Z:$ It is my pleasure.

JB: Also connected to participate in the intra-view conversation are Melisse Vroegindeweij, a co-editor of the Intra-view section of the Matter: Journal of New Materialist Research, and Magali Forte, a co-founding member of the RTD club.

MF: We are meeting online today and some of us are joining from places other than Vancouver, BC. Jacky, Melisse and I thought it would still be very important to start our discussion with a land acknowledgement, as it provides us with the opportunity to offer our respect for the land we live on and to recognize that it is not ours and that it was never ours to begin with.

Last year, our friend and colleague Kau'i Keliipio, a respected Elder and doctoral candidate, offered the land acknowledgement at the beginning of the Educational Review symposium held at Simon Fraser University. She pointed out that land acknowledgements shouldn't be considered as items on a checklist, that they aren't just scripted words that one recites, and that they are for settlers too. Her comments encouraged me to think about the questions of responsibility and privilege that land acknowledgements raise for settlers, like myself. I am a white ${ }^{6}$ uninvited descendant of French and Spanish settlers who now lives on unceded, ancestral and occupied traditional lands on Turtle Island as they are still referred to by Indigenous peoples.

With these ideas in mind, I now acknowledge that, at Simon Fraser University, on the Vancouver and Burnaby campuses, we live, learn and teach on the unceded, ancestral

${ }^{6}$ Out of respect for Black and Indigenous people, as well as for other people of color, we purposefully do not capitalize "white" throughout this article. In this sense, we follow John Horton and Peter Kraftl's (2009) notion of 'implicit activisms, "which are politicised, affirmative and potentially transformative, but which are modest, quotidian, and proceed with little fanfare" (p. 21). We invite you to think with us about the meaning of seemingly small actions, like not capitalizing the adjective white, and their political and transformative effects. 
and occupied traditional lands of the Tsleil-Waututh (səlilwətaP1), Kwikwetlem

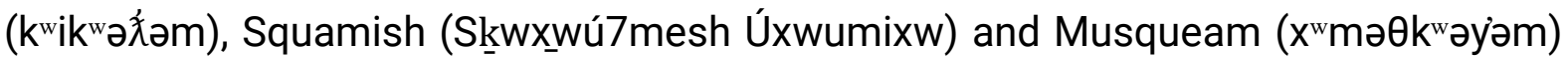
Nations of the Coast Salish peoples.

Wherever you are, I therefore encourage you to take a moment to think about who you are in relation to the land you live on, and also about what your relation is to the people that cared for it long before you or the generations before you arrived on this land. I encourage you to do so all the more today as we gather to discuss questions of decolonization and posthumanism and the tensions between them, as well as the responsibilities of non-Indigenous academics and instructors, like ourselves, for our scholarship, teaching, and learning. Thank you.

JB: We would also like to thank Nathalie Sinclair for making the initial connection between Michalinos Zembylas and the Faculty of Education community at Simon Fraser University possible via the RTD club. While the in-person event we originally planned with the support of the Research Hub team had to be cancelled due to the pandemic the world is experiencing, Nathalie has been supportive of us as we worked to arrive at this moment and have this conversation with Michalinos.

MV: Alright. Professor Zembylas, as you are associated with at least two universities in two different geographical locations, namely Cyprus and South Africa, and maybe others, we were wondering if we could start the discussion about the contexts you are writing in and how these have influenced your understanding of decolonizing practices; and then, related to that, how you situate yourself and what affective dimensions are implicated in your positionality.

MZ: Thank you Melisse. I'm writing across several contexts: Cyprus, Israel and Palestine, Northern Ireland, and South Africa to name a few. Each of these contexts influences my understanding of (de)colonizing practices in different ways. And each context, I would say, evokes affective relations and dimensions that implicate my positionality in vastly different ways.

For example, I'm writing about/from Cyprus, a place with which I have a very intimate relationship because I was born and raised here. Cyprus used to be a British colony that gained independence in 1960. Soon after, the first inter-communal clashes between Turkish Cypriots and Greek Cypriots began, dividing the country and leading 
eventually to the tragic events of 1974-the military coup d'état by extremist GreekCypriots against the government of Cyprus and the Turkish invasion in the north of Cyprus that further consolidated the division between Turkish Cypriots and Greek Cypriots. As a result of these events, Cyprus is still ethnically divided in its south and north parts; ongoing diplomatic negotiations have not managed so far to reach a solution. In this case, I'm writing from an emic perspective, and I have been doing a lot of work on peace education in this postcolonial, yet deeply conflict-affected setting. So, I have been preoccupied by the affective complexities of being involved in peace education initiatives while there is still an unresolved political problem and people become very emotional when it comes to the just solution that they envision for themselves and their ethnic community.

Now, in South Africa, you might say that I'm writing from an etic perspective, I'm an outsider. I have been doing work there in the sector of higher education for the past decade. This is another, yet a very different postcolonial setting, in which there are still many colonial structures and practices that are remnants of apartheid. So, I have been concerned with how higher education may contribute to social justice through decolonizing its pedagogical practices, curricula, and policies.

Both of these contexts (i.e., Cyprus and South Africa) have experienced different kinds of exclusions, marginalizations, and social injustices or other kinds of injustices. And so decolonization takes on different meanings and practices across these different contexts. Decolonization in Cyprus means something totally different from decolonization in South Africa or in Canada for that matter. In general, decolonization involves the deconstruction of dominant Eurocentric forms of knowledge production and the pluralization of the knowledge field. But even those practices and structures take on different meanings in different contexts. So, decolonization of higher education in Cyprus is not the same as decolonization of higher education in South Africa; the legacies of colonialism and coloniality in each setting are different and have had a different impact on higher education. So unless they are recognized first, the danger is to talk about decolonization in abstract and "metaphoric" ways, to use Tuck and Yang's (2012) terminology. 
Affectivity, which has been central in my work, is a knowledge trajectory that has systematically been ignored by Eurocentric models of knowledge, and so it's something that has been a focal point in my work on decolonization. Recently, for example, I have been writing about how the affective infrastructures and investments of education policies are very much entangled with coloniality. So it is important to examine how such policies in different settings become invested with affect to govern; in other words, education policies produce and reinforce particular affective ideologies that are associated with political ideals and visions such as coloniality. An important question and task, then, for higher education is how to decolonize the affective infrastructures and investments of education policies, curricula, and pedagogies.

MV: Thank you.

JB: I would like to point here to something you said. You said, "social justice through decolonizing practices," and this calls my attention as we've been thinking about these topics and I think that most of the time, we're thinking about decolonizing practices through social justice. But you mentioned these the other way around; social justice through decolonizing practices. I think this is one of the points that comes up when we talk about these tensions between posthumanism and decolonization. I appreciate you bringing this distinction here.

MZ: That's actually a very good point, Jacky. There are parallel debates going on in various subfields of education (e.g., human rights education, peace education, social justice education) asking whether decolonization is a subset of social justice or the other way around. I'm sure there are valid arguments and perspectives on both sides. But my question is: What do you gain, and perhaps what do you lose, each time you create these subset categories and start living as if these categories are real? And, given that my interest is mainly political, another crucial question is: How are both decolonization and social justice political projects? How can they contribute toward the same political goal?

So, you might respond "I don't really care so much which is a subset of what" as long as you're clear about your political project. Your political project may be decolonization, and it may be more appropriate in South Africa or in Canada to talk 
about decolonization as your priority. And, in some other context, for political or strategic reasons, it may be more appropriate to talk about social justice as your overall political project. So I believe that's an important debate that by no means is settled once and for all. Rather, it follows different trajectories in different contexts. I also believe that it gives you a sense of the different priorities that exist and the contextual complexities that you need to take into consideration when you talk about these concepts in different settings.

JB: Yes, and I think the importance here is to not reduce one to the other and not essentialize them either.

MZ: Right.

MV: Yes, thank you. I think that very much relates to the texts that we've read: two of your 2018 articles, namely Affect, race, and white discomfort in schooling and The entanglement of decolonial and posthuman perspectives, as well as Eve Tuck and $\mathrm{K}$. Wayne Yang's (2012) article Decolonization is not a metaphor. Tuck \& Yang (2012) mention the concept of incommensurability in relation to social justice projects and decolonization. And they also make an important note, namely that decolonization is not a metaphor. Decolonizing schools or education is incommensurable with the project of decolonization as it turns decolonizing projects into a metaphor that does not do justice to the entanglements of/and within the "triad structure of settler-nativeslave," and, at the same time, it "makes possible...a set of evasions, or 'settler moves to innocence,' that problematically attempt to reconcile settler guilt and complicity, and rescue settler futurity" (Tuck \& Yang, 2012, p. 1). They also emphasize that settler futurity should not be a central question in this decolonizing project. They also mention, in relation to all of this, that the objectives of social justice projects sometimes end up reaffirming settler logics, and those can never be complemented with decolonization. We were wondering what you think of this incommensurability and how we can avoid using decolonization as a mere metaphor in education.

MZ: I have to say that I agree with most parts of Tuck and Yang's (2012) argument, and at the same time, I have a different view on some other aspects of their argument. Let me explain. I agree that decolonization and other social justice projects might often be incommensurable-not in the sense of being incompatible, but rather, in 
terms of their political prioritization. For example, in a particular setting, it may be more politically appropriate to have decolonization as your priority. This priority may be in conflict with other social justice projects-e.g., projects on human rights-in the sense that it may not pay as much attention to coloniality as an ongoing practice. But to get there, I would also argue at the same time that, strategically and pragmatically-and I have written about this in the article you mention as well as in other pieces-we may need to become "allies" with those who advocate for other social justice projects, and start with what unites us and these projects politically. What is their common base? We may then have a common point of departure. I believe, especially in these difficult times that we live, that it may be more strategically and politically wise to start from a common base, and then move on respecting each other's priorities.

Vanessa de Oliveira Andreotti and her colleagues have talked about different approaches to decolonization and suggested this scheme that includes, for example, the "soft-reform," the "radical-reform," and the "beyond-reform" categories (Andreotti et al., 2015). "Soft-reform" is basically the lowest common denominator that increases access and inclusion of marginalized groups. Then you move to the next level, "radicalreform", where you demand more fundamental changes. And then, "beyond-reform" is the explicit recognition of colonization and the fundamental transformations of society that need to be undertaken to address coloniality. So, let's say we agree with the prioritization of decolonization, my question is contextual and pragmatic: Is it appropriate to pose this priority every time in every context? My answer is no, it depends. So, in Canada, it may be more appropriate, for example, to prioritize decolonization, and you might also argue that it takes from the energy and politics of fighting for decolonization if you have other parallel social justice projects going on. This understanding justifies Tuck and Yang's (2012) argument that decolonization and other social justice projects may indeed be incommensurable. But in other settings where there are different kinds of contextual complexities, it may be more appropriate to follow a more progressive, step-by-step approach. So you start with soft-reform and you then gradually move to radical-reform or to beyond-reform. These moves won't happen overnight though. You need to have a strategy. For example, it is important to build solidarity with others who fight for social justice. So, in light of being pragmatic and strategic, this is where I depart a little bit from Tuck and Yang (2012), 
and I differentiate my position from their argument; that it might be wiser, pragmatically and strategically, if we start from a common base, from a common denominator in some settings, not in all settings. This is precisely why the political context is fundamental in deciding which strategy and which prioritization should take place.

JB: So when we say "the political context," I think we are probably referring to something similar to the distinction Tuck and Yang (2012) made at the beginning of their article about "internal" and "external colonialism" or decolonization, and also to their discussion about settler colonial states. Being part of a Latin American country, a colonized country of settler colonial characteristics, I can certainly sympathize with this idea of prioritizing decolonial strategies and not tucking them under social justice but actually highlighting them. But of course, I follow your point that this is not the situation everywhere in the world.

MZ: I believe also that one of the points that Tuck and Yang (2012) make, which is fundamental, is the recognition of land and its appropriation by settler colonialism. You cannot have decolonization without addressing the issue of land, and this is something I totally agree with. This is true, for example, in South Africa, one of the contexts for which I'm writing. I don't believe that there can be true decolonization there without finding a solution to the ongoing problem of land appropriation. Other initiatives, especially in education, you might argue, are scratching the surface: discussing decolonization of the curriculum in higher education, for example, is valuable. However, it does not fix the fundamental problem of land appropriation. So I am with Tuck and Yang on this. But in other socio-political settings, there will probably be other priorities, and other issues will matter more. So alliances between social justice projects should be carefully considered.

JB: Yes, absolutely.

MV: Yes, thank you. We were also wondering how your idea of pluriversality relates to this idea of incommensurability. Is that also what you mean with the different contexts that matter, that different contexts prioritize certain questions over others?

MZ: The idea of pluriversality is the recognition that there are different ways of knowing, being, and feeling in the world. These different ways have to be 
acknowledged. So I certainly pay particular attention to the issue of affective dissonance as a crucial aspect of decolonization. You have to somehow feel an affective dissonance with colonized practices and with colonial continuity that are taking place today in many places in visible, less visible or almost invisible ways. You have to identify those locations, spaces where colonial continuity takes place in different forms, not only in discourse, but also in the materiality of it. This is where posthumanism and new materialism can be useful, politically and strategically. Although there are tensions between posthumanism and decolonization as mentioned earlier, and they may not be always commensurable, there is important intellectual work that needs to be done on this. So the question one may raise is: What does this actually mean in practice? How does this idea-e.g., pluriversality- translate in practice-in everyday life, in pedagogical practice, and how it is informed by theorization on posthumanism and decolonization? Because theory is good, and theorization is fundamental in the intellectual project that we are talking about. But, at the same time, one has to ask: What difference does this or that idea make in terms of actually moving us closer to decolonization, rather than falling into the trap of perpetuating coloniality in forms that we don't even realize or we are not even able to identify? For me, these are open questions that have to be raised each and every time we engage with decolonization projects. There are no predetermined answers to these questions. It's part of our intellectual and political project to engage with them in situ, particularly in terms of how these theoretical ideas can be translated into specific decolonizing pedagogies and practices.

MF: I really appreciate what you just said, Michalinos, and how you connected our thinking practices and our reading practices to our pedagogical intentions as educators. This question really resonates with a question I believe a lot of educators have in mind: How do we make a difference at the end of the day in a respectful way? One of the questions that I wanted to ask comes from your call, at the end of your 2018 piece The entanglement of the colonial and posthuman practices, for "educators, researchers, policy-makers in higher education ... to learn how to make better use of the relative privilege that we have to become a better ally to those directly exposed to the everyday realities of coloniality - both within and beyond the academe" (Zembylas, 
2018, p. 264). You've touched upon it a little bit earlier, but I would like to talk a bit more about it as some have argued that the use of the term "ally" can be problematic. Let's take Kim TallBear for example. She is an enrolled Sisseton-Wahpeton Oyate citizen, descended from the Cheyenne and Arapaho Tribes of Oklahoma, and she is currently working at the University of Alberta, and is also a Canadian Research Chair in Indigenous Peoples, Technoscience and Environment. I listened to her conversation with Adrienne Keene and Matika Wilbur who have an excellent podcast called All My Relations. They discussed how problematic this idea of ally can be, and I'm wondering how we can avoid falling into what Tuck and Yang (2012), taking after Janet Mawhinney's (1998) concept, call a "settler move to innocence" (p. 10). Does the notion of being an ally itself risk maintaining a view of academia and the world in which white privileged people, like myself, remain exactly who and where they are - i.e., people who want to help others by being their allies, because they believe these others are in need of their help, thereby reproducing a form of racialized hierarchy of self vs. others? TallBear offers the notion of "standing with" rather than giving back, ${ }^{7}$ and I find that it might be productive for us to think in these ways too. What do you think?

MZ: That's an excellent question and I like TallBear's idea of "standing with," but let me start by agreeing that, yes, the notion of ally may entail problematic assumptions if it maintains, in an essentialist way, the division between those who are privileged and those who are less privileged. I am afraid this can happen with any kind of terminology and concept that you may choose to use. So you have to qualify your terms. If you're talking about an ally, what exactly do you mean and in which context are you talking about this? Because it has been used, for example, in social justice literature in various contexts as a way of building solidarity or of cultivating "affective solidarity" to use Clare Hemmings's (2012) term. I believe that solidarity is an important idea that has to be, once again, qualified. So when I use the notion of ally, in a context of building affective solidarity to open ethical and political possibilities for change, it's one way of feeling for/with colonized others; it's a way of transforming

\footnotetext{
${ }^{7}$ In her 2014 piece, Kim TallBear stresses the fact that, as a researcher working with/in Native American communities, the idea of giving back "does not capture [her] method or ethic" (p. 1) as it maintains a boundary between subjects/participants and researchers. In an effort to "approach knowledge production from shared conceptual ground" (p. 2), she articulates her inquiry approach as "feminist-Indigenous," and puts forward the ethical orientation of "standing with" which offers a view of research "as a relationship-building process, as a professional networking process with colleagues (not 'subjects'), as an opportunity for conversation and sharing of knowledge, not simply data gathering" (p. 2).
} 
ourselves in the world. This may be problematic if you don't qualify it. So empathizing with others who suffer, or claiming that you can feel for or feel with the Other, can be problematic, if it ends up being an empty or cheap sort of sentimentality, or a superficial sort of feeling such as pity - i.e., pitying the Other. So I would still use the notion of being an ally because it gives me the power of making an intellectual argument about solidarity which I think is fundamental for the kind of work that I'm doing or for what I'm arguing. It's a political position. But I do recognize that there are dangers if you don't qualify the term, if you don't contextualize it. And I certainly like the idea of standing with, which for me is another way, you might say, of being an ally to somebody - if you don't patronize the Other and if you don't speak from a position of power. You need to keep all these qualifiers in mind when you use these concepts. JB: I think the idea of ally brings for me a little bit more action than standing with, and I've discussed with Magali before that standing with also implies thinking with. You cannot stand with if you don't think with; being intellectually engaged with, in this case Indigenous epistemologies, as well as being able to stand with and support the work of others. But the idea of ally, and I'm thinking of it more in the context of pedagogies or methodologies in the classroom, gives me a little bit of power, in the sense of doing something. It allows me to do something in my own classroom as an instructor towards the Other in general, but also in the work I do with my students and the curriculum I develop. As you were just saying, and bringing that back to what you were saying before, I think the context will determine which position as a non-Indigenous instructor and scholar I should take. So, in some instances, being an ally might be the way to go, and in others, it might be standing with in very respectful ways.

MZ: And for example, what do you mean when, as a teacher, as a white teacher, as a white privileged male educator, like myself, you claim to be an ally to non-white students or Indigenous students? These are difficult questions and they're not easy to answer. But there are ways through pedagogical practices and strategies to at least acknowledge the complexities involved and try to address some of those in the best way you can without perpetuating colonial relations. Therefore, it is crucial to start with acknowledging that you live in a fundamentally colonial system. And unless we start by acknowledging this and its terrible consequences (e.g., injustice), it would be 
an illusion to believe that, by using fancy pedagogical practices and changing the university curricula, these colonial structures and relations will disappear. Educational reforms are not an "alibi" (Leonardo \& Zembylas, 2013) for the fundamental changes that are needed on the level of social structures.

So, I believe that we have to be realistic about what we can do and we can't do in the field of education. And if we are realistic and pragmatic, we may have more chances of challenging or even dismantling this colonial system step by step. It's not going to happen from one day to the next, and it's certainly not going to happen through education alone. It has to happen on multiple levels of the society at the same time, and that's why another set of questions is: Do educators have a responsibility to educate outside the classroom, outside formal settings? Do educators need to play this pedagogical role outside the typical formal classroom, in the community, and do activist work? And that's where the word ally may have more sense, because, as Jacky was saying, it has more connotations with action, when you do something. It's not only words anymore, which are nevertheless important in the process of intellectually problematizing colonial relations. But obviously, words are not enough. You have to engage in some sort of action, within schools and outside schools, to be able to bring some change.

JB: I've noticed that sometimes teachers might take this responsibility, but also sometimes the responsibility to fix society's issues is put on teachers' shoulders. And this, of course, is not possible. There is only so much that a teacher can do, even if they are aware and willing to do so. I also think that, as teachers, we do have a responsibility as well outside of the classroom, but so does anybody else. I don't think it's because we are teachers, I think it's because it's a matter of being a citizen, the citizen of a country, of the world, of a region, of being human - it's our responsibility to try to make things better.

I want to bring in the issues that we face in the classroom with white students, which was one of the problematics and the tensions that we wanted to discuss. I've been teaching a diversity course, which can make it a bit easier to approach these issues and these discussions because students taking the course are aware that they are going to learn about diversity. So there might be more willingness to have these 
discussions. But still, as an instructor, I face this issue, and especially as a non-white person, you face white students in the classroom and the whole gamut of their responses to the issues being discussed kind of invades the space. You have the silence, you have the avoidance, you have the anger, although not always manifested openly. So, I'm thinking about racism in Canada (and in Latin America as well) in relation to Aboriginal people and decolonization. Of course, racism looks different in different situations and in different geographical locations. But when discussing racism in the classroom, as an instructor, I sometimes feel torn over how to handle these responses. They become quite loud, even if they're not speaking, they become loud in the classroom. And you have to do something and you have to acknowledge them, but at the same time, you don't want to center the discussion around white students' feelings and expressions, as the idea would be to direct the work towards the voices that are usually silenced. I'm bringing these issues here, and I know a lot of you face similar situations and I wanted to hear your opinion.

MZ: I think first of all it's important to acknowledge the different kinds of feelings that white students may experience, which have been referred to in different ways: "white discomfort" (Zembylas, 2018a), "white fragility" (DiAngelo, 2011; DiAngelo, 2018) or "white guilt" (Essed \& Trienekens, 2008 cited in Leonardo \& Zembylas, 2013). All these have different meanings and connotations, depending on the context. First of all, it is important to identify what you have in your classroom, namely, which kind of feeling(s) and why. Secondly, it is crucial to remember that white emotionality is socially and politically produced within material, affective, and discursive structures of whiteness and white supremacy. So it's important to remember that this issue is not individual as such; it's social and political. It's produced socially and politically. I'm saying this, because we need to avoid blaming the individual. This doesn't mean that you let the individual off the hook. Each individual has responsibility and agency, but I believe it's important to remember that the challenge we are dealing with is social and political. We shouldn't psychologize the problem, because we would then depoliticize it. I am emphasizing this because the pedagogies that we will use to address this issue are going to be totally different when we identify the challenge through a lens that recognizes the affective politics involved, compared to a different lens that would see it as an individualized or a psychologized issue (Bekerman \& Zembylas, 2018). 
Certainly, inventing pedagogies that address various forms of white emotionality is extremely difficult for teachers and students alike, all students, for different reasons, of course. I think there is growing literature in recent years on this topic. For example, Cheryl Matias and I wrote about the emotions of white students and how they respond or react to difficult discussions about diversity, whiteness, and race in the classroom (Matias \& Zembylas, 2014). One of the things that we found out is that there has to be a step-by-step approach that includes various strategies, depending on the audience you have in the classroom. For example, sometimes you may need a pedagogy of "strategic empathy" with white students-which does not imply letting them off the hook. But you actually have to build an affective atmosphere in the classroom that is conducive to have these difficult conversations. You cannot expect to have these difficult conversations if you don't build some sort of trust as an educator in the classroom. That students can trust you, that you're not going to blame the individual, but at the same time you will hold them accountable for the responsibilities that they have in this, and they do. Each one of us has his/her own responsibility and complicity, but we are not all responsible for everything and in the same manner or degree. Because as Hannah Arendt (1972) said, "When all are guilty, no one is." In other words, if everybody is responsible for everything, then nobody is really responsible for anything. So it's important to remember that we are all complicit, and yet there is differential complicity. As a white privileged male, I have a lot of responsibility and complicity because I am benefitting every day from the structures that are in place. I cannot expect somebody else to have the same responsibilities. If $I$, then, as a white privileged male, if white people in general, don't take a clear stance against colonial/colonized/colonizing practices not in theory, but in how we live our everyday lives, then I am afraid there is not much hope in actually changing colonial structures. MF: I want to try and weave in some of the comments that have appeared in the chat, while you were elaborating on this important point, Michalinos. People have an interest in hearing more about the idea of adopting an ethics of critical affect, and I think that this is part of what you've just explained, by bringing up the importance of not only responsibility but also complicity. 
Roumiana Ilieva (Simon Fraser University [SFU]):

I wonder if we can hear more about the notion of adopting an ethics of critical affect.

Suzanne Smythe (SFU):

Yes, l'd like to hear about critical affect from Michalinos.

MF: And I'll add one more comment here because you just brought up complicity, and I think that may allow for a slight shift from the notion of being an ally.

\section{Kari Gustafson (SFU):}

There is a move toward the position of accomplice rather than ally - while I realize this is a language difference, it does seem to promote action in solidarity?

MF: Does Kari's question maybe change and augment the lens that you were offering, Michalinos?

MZ: Sure. Let me elaborate first on the point about "critical affect." Take, for example, the notion of "critical empathy" which is distinguished from naive or sentimental empathy. The difference with critical empathy is that you take a critical position, a critical stance in the classroom. You don't simply empathize with the Other; you critique your own position, you acknowledge your own complicity, you recognize that you're privileged, and you take action to address your complicity. What is crucial, then, is whether you are politically, ethically, and pedagogically willing to take a stance and move forward to transform yourself and, to the degree that you are able to do this, to transform your surroundings, the world around you. This is an ethics of critical affect. A pedagogy that cultivates critical affect, then, is the approach that not only evokes critical emotions and feelings, but one that actually encourages you or makes you take action that makes a difference to people's lives. 
Now, Kari's question whether there is a move toward the position of "accomplice" rather than ally makes a good point, namely, the word accomplice entails taking action to help someone. So, I believe this term could foreground more powerfully the idea of action in solidarity-which certainly includes the role of the body and materialitycompared to the notion of ally which might be weaker in these terms.

JB: This reminds me of Spinoza's (1949) definition of the body, of the affective capacities of bodies that he wrote about. The reality is that affecting and being affected is a constant process. I think that when we only engage at the conscious level, or at the cognitive level, it has its repercussions as well. It's not that our bodies are not engaging in other ways, they are, but probably not in positive ways, they are probably not moving forward social justice or decolonizing practices. So, I think that if we are not taking positive action as a dimension of critical affect, having these two components - thinking and action, then we are probably supporting the status quo.

MF: And it's such a fine line to navigate too. I'd like to go back to the notion of being an ally.

Kau'i Kaliipio (SFU):

Does standing with provide the opportunity to learn

from while in the process of being in relationship?

Rather than the sense of imposition when identifying as ally.

Suzanne Smythe (SFU):

Ally is a relationship, one should be claimed as an ally not claim oneself as an ally...

MF: Thinking with Kaui's comment, and what you both said, Michalinos and Jacky, if we don't take action, then we just stay at that level of words, we don't get to the level of critical affect that taking a stance or taking action requires. And that is what will make a difference to our lives and to other people's lives. So, it's a delicate boundary to navigate, to remain respectful in our relations, to work to maintain these relations, to be in good relations and earn respectful relations with Indigenous people in our 
context. And you said that many times, Michalinos, it depends on the context. In Canada, colonizers were never invited on this land, I was never invited on this land, I never asked for permission, and yet I'm here. So how do I establish and maintain good relations with Indigenous people in a respectful manner, taking action, but also not overstepping and not doing or saying things for other people, not making it worse in a certain way?

MZ: There is no recipe for that, Magali. Nobody can tell you beforehand what you need to do in Canada to be able to not overstep and appropriate other people's lives and epistemologies, or to be respectful. This is something you have to negotiate, in good faith and with respect- especially with the people who are less privileged, who have been colonized, while you benefit from colonization everyday. But words are not enough to show your respect; as you say, you need to take action. Action on several levels, on an everyday basis, that challenges and dismantles colonial relations and practices. You will have to be taught by Others (e.g., Indigenous people) how not to overstep and misappropriate their lives and epistemologies.

To make a link to Kaui's question, then, the answer is yes-“standing with" can indeed provide opportunities to learn from or be taught by Others what it means not to misappropriate them, what it means to stand with them in the struggle for decolonization. Rather than being self-imposed as an ally (besides, one may ask, "who appointed you to be an ally?"), it may be crucial to cultivate relationships of standing with/being with Others.

MF: Thank you. We have another question.

Diane Dagenais (SFU):

If critical affect entails actions that make a difference,

who decides what actions make a difference?

MZ: That's a very good question. Who decides what actions make a difference? Again, I would begin by saying that this is a process of negotiation. What are the demands of a given context? What exactly does a particular context require to move from a colonial practice to decolonizing practices? So it is the particular demands that will actually determine which actions make a difference. It's not an individual decision. It's 
a process of social and political negotiation. This is why it's important to engage in activism. Here I am not talking about grand activism, but rather about what some scholars call small acts of activism, "implicit activisms" (Horton \& Kraftl, 2009). These are everyday actions that make a difference to people's lives. They are actions that make a contribution towards social justice or decolonization projects; they're not actions that simply make us feel good. Therefore, if we are talking about critical affects, then it means that these affects are not cheap sentimental expressions but rather actions that make a difference-even a small one- in the struggle against colonial practices and relations.

JB: I think that this also resonates with the concept of ethics that Spinoza provides, where my actions are not based on a moral code imposed by God, or society, or anybody else. But it's an ethics about how I relate among all the entanglements that I am part of. It is about what my responsibilities inside those are, or, thinking with Barad (2007), my "response-ability": How I respond to each situation, and this will be different for everyone, every time, and it will constantly be different as well; even for the same person, it will change. So it's in every encounter, in every event that we need to face this response-ability, ethically, in how we engage in life continuously, in all our entanglements.

MV: Are there any more questions in the chat or comments that we should address? MF: Yes.

Roumiana llieva (SFU):

How are small acts of activism in a classroom similar

or not to subversive pedagogies?

MF: We've been talking about affective pedagogy, critical affect, and now there's this notion of subversive pedagogies.

MZ: Before answering Roumiana's question, let me clarify further what I mean by these small acts of activism and how they can be subversive. These small acts of activism in the classroom can be subversive in the sense that they challenge the status quo. Some are more subversive than others, of course. One example would be to see somebody being discriminated against in a line, and then take a position, take a 
stance, and respond to it by engaging in an act that challenges this act of discrimination. That's a small act of activism if it's not simply done out of kindness or superficial compassion, and rather it's a political position, because you want to send a political message through this act. So you might argue it's subversive because it challenges somewhat the status quo of taken-for-granted privileges: For instance, the perception that individuals belonging to a particular gender, class, race, or nationality can skip the line and go before others. These acts may be subversive, however, they don't bring down the whole system of privileges. So, it's important to be critically conscious about the pragmatic effect of small acts of activism.

Let me address now the second part of the question, namely, whether these acts of activism constitute some sort of subversive pedagogies. First of all, when you engage in an action, it doesn't mean that you also engage pedagogically with others. Pedagogical engagement requires that you have some sort of goal in mind. So, in this sense, one might argue that not all acts are pedagogical because they do not always aim at teaching someone something on purpose. A pedagogical act requires that you're considering the goal and the way you engage with the public, with your students. Therefore, if these small acts of activism entail some pedagogical goals, then you may argue that they also constitute subversive pedagogies.

MF: Thank you, yes. We have one last question coming from our chat participants.

Cher Hill (SFU):

I appreciated this insight into potential dangers of post-human perspectives: “... when certain people have never been treated as humans-as a result of ongoing colonial practices- post-human approaches advocating a move away from humanism might be seen as an alibi for further denial of humanity to these same people" (Zembylas, 2018b, p. 255). Can Michalinos say more? 
MF: Thanks, Cher, for bringing us back to our initial question about the tension between posthumanism and decolonization. Michalinos, could you say a bit more about this tension?

MZ: Yes. My point here is that decolonial and posthuman approaches do not always have the same priorities. As I have written in the article from which you cited, my concern is with how a posthumanist approach may be perceived when the denial of humanity is a matter of fact. About the denial of humanity in colonial settings, the work of Sylvia Wynter is helpful. For example, Wynter $(2003,2015)$ traces the trajectories of the human as those are linked to colonial practices. So if we argue that the human ought to be abolished in favor of post-humanism, isn't there a danger here to deny humanity to those who haven't even been recognized as such (e.g., colonized people)? The point that I am making here, in agreement with the work of other decolonial theorists, is that we need to keep a critical eye when we put into conversation decolonial perspectives with posthuman ones; their entanglements may be (un)productive or reproductive of the same colonial structures we are attempting to dismantle. Therefore, the questions we ought to be asking are: What does this decolonial-posthuman entanglement do? What does it allow you to do? And perhaps, what do you lose by using posthumanism if your goal is decolonization? If your goal is to prioritize decolonization, one might question whether you actually need posthumanism to serve this project. So I'm not saying that they shouldn't be used together. I'm just saying that we have to be conscious that using them together entails intellectual and political consequences and implications that need to be spelled out.

JB: I'm thinking about a distinction that may be useful here because one thing is how we conceptualize "the human," and this is a concept coming from the Enlightenment, and another thing is when we think of humans as the human race in general or broadly speaking. So, when we think of the concept of the human, we certainly want to move away from that because we don't want to, or at least / don't want to, be conceptualized in that way. I will never make the measure. So it's a useless concept and, in that sense, it shouldn't be used. So we definitely want to be post from that concept. But when we think of humans, of course, we don't want to be post, in the sense of posthuman of the human race. We want to reconceptualize this concept so that we all can fit in this new conceptualization. Expanding maybe this idea of the human so that it embraces 
difference, which is inherent in being human, so that we don't set limits, and just absolutely leave it open to who is or not human. And do we even need the distinction? So in one sense, if we are speaking of the concept, yes, we definitely want to move away from that, and I think that, at least from my perspective, that's what posthumanism allows me to do, to move away from that, and to open this concept to where we don't even need to think of this. So that, you know, the whole world comes in at that moment, the relationality, the performativity of the world comes in.

MZ: Right. But historicizing the human, I believe you can clearly see that the human has meant, in most cases, and still means the white man. So, there is no way you can erase colonial history.

JB: Yes, exactly. And I think bringing history to the forefront is one thing posthumanism allows us to do. And so, maybe this is why I see some productive engagement with the decolonizing project.

MZ: Certainly, there are productive engagements if you find the resonances and their allowances when you diffract these two concepts together instead of making them oppose each other.

JB: Absolutely. Yes, diffraction is a very useful concept here.

MV: Alright. I'm sorry to say that we're nearing the end of the time that we have, already. So I want to ask if anybody, including chat participants, has any final remarks they want to make?

MF: They're [participants in the chat] making sad faces.

[laughs]

MF: Nathalie Sinclair, from SFU, wants to share some thoughts with us via microphone. 
Nathalie Sinclair (SFU):

And I really like the idea of nepantla which comes from the Nahuatl people (Anzaldúa \& Keating, 2002; Gutiérrez, 2012) who talk about this "interstitial" space between worlds and who invite a sort of thinking of this and that by pointing at the interstitial world between this thing and that thing. So, I think that's a mathematical and an Indigenous way of opening up our logics around things like incommensurability so that they don't preclude certain action. And I think, as Michalinos said, that this way of talking about how those interstitial spaces really depends on what it is that you want to accomplish plus the recognition of the choice that you're making, of the contingency of your choices, is really important and keeps alive the tension that arises from seemingly opposite or contradictory places.

MZ: Yes.

Nathalie Sinclair (SFU):

I can't help, of course as a mathematician, to notice the prevalence of certain logics that are at play in some of our ways of talking. It came up a lot in terms of the inclusive-exclusive kinds of relations that we have been alluding to and that are dependent on a certain kind of spatial logic that we inherit from Kant. As Fred Moten says, Kant's white logic precludes certain relations that are not possible in a fixed and distinct conception of space and time. But also, the very idea of incommensurability, which comes from the ancient Greeks, literally means that you can't measure one in terms of the other. But of course, there are many geometric shapes that have both irrational and rational sides like the triangle. I'm not going to continue to talk about Math. My point is just that incommensurable doesn't mean that you can't have both at the same time. 
MZ: Thank you, Nathalie. This is an excellent point to keep in mind. The idea that something is incommensurable as such is grounded in a Western epistemology which is different from some Indigenous epistemologies, or other sorts of epistemologies, that emphasize different ways of seeing, being and living in the world. I believe this is a wonderful point to end this conversation!

$\mathrm{JB}, \mathrm{MF}$, and MV: Yes, thank you.

We want to thank Michalinos Zembylas for sharing his time and knowledge with us and engaging in this conversation. We would also like to thank all the attendees and participants from the chat for joining us and for making our conversation so much richer with their questions and comments.

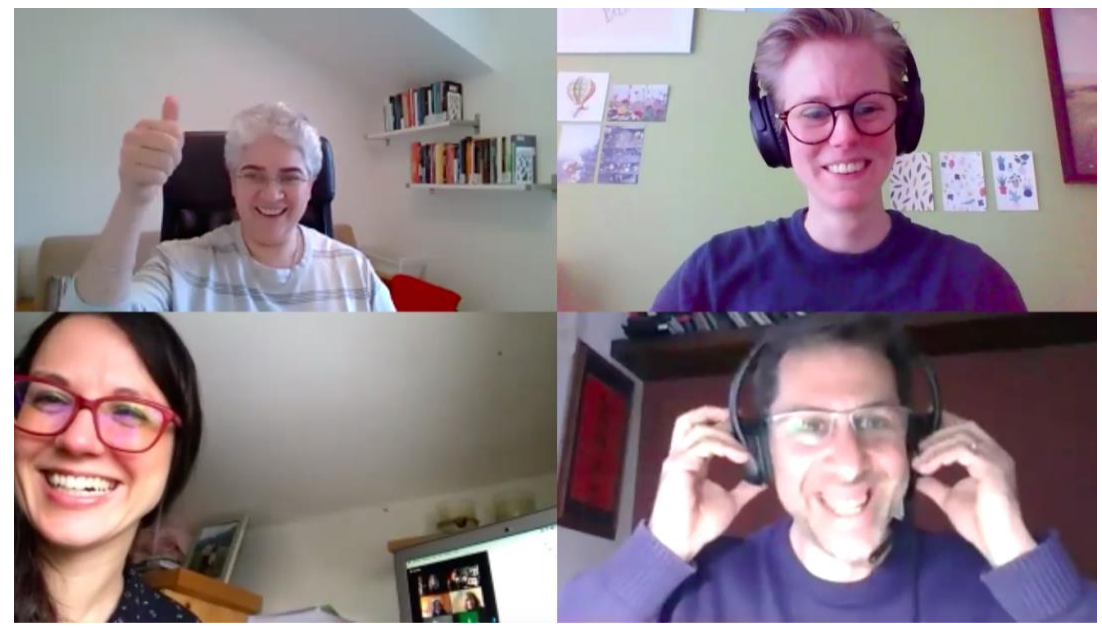

A screenshot from "Posthumanism, education, and decolonization:

A conversation with Michalinos Zembylas." Top left: Jacky Barreiro, top right: Melisse Vroegindeweij, bottom left: Magali Forte and the participants via the chat, bottom right: Michalinos Zembylas.

\section{Bibliography}

Andreotti, Vanessa, Sharon Stein, Cash Ahenakew \& Dallas Hunt (2015). Mapping interpretations of decolonization in the context of higher education. Decolonization: Indigeneity, Education \& Society, 4(1), 21-40. Retrieved April 22, 2020, from http://representing-education.gertrudecotter.info/wp- 
Anzaldúa, Gloria \& Analouise Keating (2002). This bridge we call home: Radical visions for transformation. New York: Routledge.

Arendt, Hanna (1972). Crises of the republic: Lying in politics, civil disobedience on violence, thoughts on politics, and revolution (Vol. 219). Houghton Mifflin Harcourt.

Barad, Karen (2007). Meeting the universe halfway: Quantum physics and the entanglement of matter and meaning. Durham: Duke University Press.

Barreiro, Jacky, \& Melisse Vroegindeweij (2020). New materialist becomings and futurities: A panel intra-view. Matter: Journal of New Materialist Research, 1(1), 138154. doi: https://doi.org/10.1344/jnmr.v1i1.30132

Bekerman, Zvi, \& Michalinos Zembylas (2018). Psychologized language in education: Denaturalizing a regime of truth. New York: Palgrave Macmillan-Springer.

DiAngelo, Robin (2011). White Fragility. International Journal of Critical Pedagogy, 3(3), 54-70. Retrieved April 22, 2020, from http://libjournal.uncg.edu/ijcp/article/view/249 DiAngelo, Robin (2018). White fragility: Why it's so hard for white people to talk about racism. Beacon Press.

Essed, Philomena, \& Sandra Trienekens (2008). 'Who wants to feel white?' Race, Dutch culture and contested identities. Ethnic and Racial Studies, 31(1), 52-72. doi: $10.1080 / 01419870701538885$

Gutiérrez, Rochelle (2012). Embracing "Nepantla:" Rethinking knowledge and its use in teaching. REDIMAT-Journal of Research in Mathematics Education, 1(1), 29-56. doi: 10.4471/redimat.2012.02

Hemmings, Clare (2012). Affective solidarity: Feminist reflexivity and political transformation. Feminist Theory, 13(2), 147-161. doi: 10.1177/1464700112442643 Horton, John, \& Peter Kraftl (2009). Small acts, kind words and "not too much fuss": Implicit activisms. Emotion, Space and Society, 2(1), 14-23. doi: 10.1016/j.emospa.2009.05.003

Keene, Adrienne \& Matika Wilbur (2019, March 12). Can a DNA test make me Native American? All My Relations Podcast. Accessed April 22, 2020, on 
https://www.allmyrelationspodcast.com/podcast/episode/33235119/ep-4-can-adna-test-make-me-native-american

Leonardo, Zeus \& Michalinos Zembylas (2013). Whiteness as technology of affect: Implications for educational praxis. Equity \& Excellence in Education, 46(1), 150-165. doi: 10.1080/10665684.2013.750539

Matias, Cheryl \& Michalinos Zembylas (2014). 'When saying you care is not really caring': Emotions of disgust, whiteness ideology, and teacher education. Critical Studies in Education, 55(3), 319-337. doi: 10.1080/17508487.2014.922489

Mawhinney, Janet (1998). 'Giving up the ghost': Disrupting the (re)production of white privilege in anti-racist pedagogy and organizational change. Master's thesis, Ontario Institute for Studies in Education of the University of Toronto. Available at: http://www.collectionscanada.gc.ca/obj/s4/f2/dsk2/tape15/PQDD_0008/MQ33991. pdf

Spinoza, Baruch (1949). Ethics. New York, NY: Hafner Publishing

TallBear, Kim (2014). Standing with and speaking as faith: A feminist-indigenous approach to inquiry. Journal of Research Practice, 10(2), Article N17. Retrieved April 22, 2020, from http://jrp.icaap.org/index.php/jrp/article/view/405/371

Tuck, Eve \& Wayne Yang (2012). Decolonization is not a metaphor. Decolonization: Indigeneity, Education \& Society, 1(1), 1-40. Retrieved April 22, 2020, from https://jps.library.utoronto.ca/index.php/des/article/view/18630

Wynter, Sylvia (2003). Unsettling the coloniality of being/power/truth/freedom: Towards the human, after man, its overrepresentation-an argument. CR: The New Centennial Review, 3(3), 257-337. https://doi.org/10.1353/ncr.2004.0015

Wynter, Sylvia, \& Katherine McKittrick (2015). Unparalleled catastrophe for our species? Or, to give humanness a different future: Conversation. In K. McKittrick (Ed.), Sylvia Wynter: On being human as praxis (pp. 9-89). Durham, NC: Duke University Press. https://doi.org/10.1215/9780822375852-002 
Zembylas, Michalinos (2018a). Affect, race and white discomfort in schooling: Decolonial strategies for 'pedagogies of discomfort'. Ethics and Education, 13(1), 86104. doi: $10.1080 / 17449642.2018 .1428714$

Zembylas, Michalinos (2018b). The entanglement of decolonial and posthuman perspectives: Tensions and implications for curriculum and pedagogy in higher education. Parallax, 24(3), 254-267. doi: 10.1080/13534645.2018.1496577

\section{About the authors}

Jacky Barreiro is a doctoral candidate in the Faculty of Education at Simon Fraser University where she also works as an instructor. Together with Melisse, she is the coeditor of the Intra-view section of the Matter: Journal of New Materialist Research. In her scholarship, she is interested in posthumanist and new materialist theories insofar as they provide a new way of understanding the relational and performative role of human and nonhuman agency in educational practices. Her doctoral inquiry focuses specifically on the educational implications of posthumanist theories as pedagogical tools of critique. It addresses the sociomaterial relations entangled in social justice in education by exploring her practice as teacher and principal for ten years in a rural school in the high Andes in Ecuador with a mostly mestizo population.

Melisse Vroegindeweij is a research master student of the program Media, Arts and Performance studies at Utrecht University. She is also a co-editor of the Intra-view section of the Matter: Journal of New Materialist Research. Her current research interests are the climate crisis, environmental racism, and responsible storytelling. Her thesis project will be about the imaginaries of water and the future of water in The Netherlands.

Magali Forte is a doctoral candidate, a research assistant and an instructor in the Faculty of Education at Simon Fraser University. She is also a co-founder of the Reading/Thinking/Doing club. And she is a teacher in the elementary and secondary schools of Vancouver. Her research interests focus on exploring the potential of posthumanist theories to open up different ways of examining processes of identity construction in multilingual and multimodal environments. While doing so, she wants 
to do her best to be mindful of, and highlight that many aspects of posthumanist theories owe much to Indigenous perspectives that have embraced a relational view of identity for a very long time.

Michalinos Zembylas is Professor of Educational Theory and Curriculum Studies at the Open University of Cyprus and Honorary Professor, Chair for Critical Studies in Higher Education Transformation at Nelson Mandela University, South Africa. He has written extensively on emotion and affect in relation to social justice pedagogies, intercultural and peace education, human rights education and citizenship education. His recent books include: Critical Human Rights Education: Advancing Social-JusticeOriented Educational Praxes (with A. Keet), and Socially Just Pedagogies in Higher Education (co-edited with V. Bozalek, R. Braidotti, and T. Shefer). In 2016, he received the Distinguished Researcher Award in "Social Sciences and Humanities" from the Cyprus Research Promotion Foundation.

\section{About the contributors (in order of appearance)}

Roumiana llieva is an Associate Professor in Additional Language Education at the Faculty of Education at Simon Fraser University. Her research interests include internationalization of higher education, language teacher identities and agency, academic identity construction, interdisciplinary collaborations for multilingual student success, language and culture, migration, and integration.

Suzanne Smythe is an Associate Professor in Adult Literacy and Adult Education in the Faculty of Education at Simon Fraser University. She is currently interested in new material and posthuman thinking, new literacies of automation, and more ethical human-machinic futures.

Kari Gustafson is a PhD student in Philosophy of Education at Simon Fraser University, with an ME from Aarhus University in Copenhagen, Denmark. Her research focus is neurodiversity and social marginalization. Kari is currently exploring social and learning practices in Dungeons \& Dragons and other roleplaying communities.

Kau'i Keliipio identifies as a Kanaka Maoli, Indigenous Hawaiian, cisgender female. Having had the privilege of living as an uninvited guest/settler on unceded and 
traditional lands of the Coast Salish peoples, she takes up her kuleana, responsibility to ensure that Indigenous children and youth indeed all children to flourish in their educational endeavors.

Diane Dagenais is a Professor in the Faculty of Education at Simon Fraser University where she teaches in French and English Language Education. Informed by new materialism and posthumanism, her recent research in applied linguistics documents encounters of multilingual learners, digital tools and literacy practices in and out of school.

Cher Hill is an Assistant Professor of Professional Practice and a teacher educator in the Faculty of Education at Simon Fraser University. Her current scholarship utilizes new materialist theories to make visible the complex relationships between humans and more-than-humans within educational contexts. Cher embraces research that is unbounded, and located in the spaces between universities and communities.

Nathalie Sinclair is a Canada Research Chair in Tangible Mathematics Learning at Simon Fraser University and a professor in the Faculty of Education. She has written several books including the co-authored Mathematics and the Body: Material Entanglements in the Classroom, as well as over 75 journal articles. 